Studia

z Filologii Polskiej

i Stowiańskiej

DOI: $10.11649 /$ sfps.1930
Studia z Filologii Polskiej i Słowiańskiej, 55

Warszawa 2020

Article No. 1930

Citation:

Садова, Л. О. (2020). Сімейно-родові іменування, похідні від імен та прізвищ першоносіїв (на основі вибраних антропонімів сіл Антонівка та Борисковичі початку та середини ХХ століття). Studia z Filologii Polskiej i Stowiańskiej, 55, Article 1930. https://doi.org/10.11649/sfps.1930

Sadova, L. O. (2020). Simeinno-rodovi imenuvannia, pokhidni vid imen ta prizvyshch pershonosiï (na osnovi vybranykh antroponimiv sil Antonivka ta Boryskovychi pochatku ta seredyny XX stolittia). Studia z Filologii Polskiej i Słowiańskiej, 55, Article 1930. https://doi.org/10.11649/sfps.1930

Лариса Олександрівна Садова

(Волинський національний університет

імені Лесі Українки, Луцьк)

\title{
Сімейно-родові іменування,
}

похідні від імен та прізвищ першоносіїв

\section{(на основі вибраних антропонімів сіл Антонівка} та Борисковичі початку та середини XX століття)

Потреба у вираженні родинних відносин у слов'ян була споконвіку. Відчуття роду і родини дає людині відчуття повної безпеки, захисту, опори у скрутні хвилини життя (Осташ, 2001, с. 411). Рід, яким жили наші давні предки-язичники, був суспільним об’єднанням, яке грунтувалося на усвідомленні свого походження від спільного предка, хоча 6 навіть фіктивного. Спираючись на таке тлумачення свого походження, представники певного роду відособлювали себе від інших (Пахомова, 2012, с. 35).

Сімейно-родові іменування досі збережені в слов'янських антропонімних системах, здебільшого в сільському антропоніміконі. У сільській місцевості люди краще знають один одного, ніж у місті, тому в селі прізвисько $€$ значно актуальнішою особовою назвою. У селі в розмовній мові

This is an Open Access article distributed under the terms of the Creative Commons Attribution 3.0 PL License (creativecommons.org/licenses/by/3.0/pl/), which permits redistribution, commercial and non-commercial, provided that the article is properly cited. (c) The Author(s) 2020.

Publisher: Institute of Slavic Studies, Polish Academy of Sciences

[Wydawca: Instytut Slawistyki Polskiej Akademii Nauk] 
прізвище використовують рідко, люди відомі під різними прізвиськами (Чучка, 2008, с. 157). Однією з причин активного функціонування сімейно-родових іменувань $€$ повторюваність прізвищ у межах населеного пункту. Належність до певного роду виявлялася на антропонімному рівні через систему сімейно пов’язаних імен (поодинокі випадки таких іменувань на півдні Волинської області були збережені до кінця XIX ст.), а також через спадкові родові назви, які функціонували як своєрідні родинні прізвиська та вказували на спільного для родини чи роду предка.

В українській антропоніміці немає усталеного терміна для позначення цих іменувань. Більшість дослідників відносить їх до складу прізвиськ, указуючи на їхній специфічний статус. П. П. Чучка називає ці антропоніми родичівськими прізвиськами або генесіонімами (Чучка, 2008, с. 197). Г. Є. Бучко та Д. Г. Бучко використовують термін сімейно-родові (спадкові) іменування, зазначаючи, що «такі назви відрізняються від індивідуальних прізвиськ і наближаються за рядом ознак до прізвищ, зокрема мають близьку лексичну базу та однакові словотвірні моделі» (Бучко \& Бучко, 2002, с. 303).

У польській ономастичній літературі для позначення сімейно-родових іменувань використовують термін придомок, називаючи придомками спадкові неофіційні особові іменування, які позначають родину, а також не мають емоційного забарвлення, не характеризують носіїв, а лише їх називають (Biolik, 1983, с. 172).

Питання функціонування та структури неофіційних іменувань (серед яких і сімейно-родові) розглянуто в працях польських (Cieślikowa, 1998, Lindert, 1966, Sajewicz, 1999, Sychta, 1956, Tomczak, 1999), словацьких (Blanar, 1998), білоруських (Бірыла, 1966), чеських (Beneš, 1962, Kazík, 2016) дослідників. Функціонування сімейно-родових іменувань у сучасному українському антропоніміконі вивчали Г. Є. Бучко та Д. Г. Бучко (Бойківщина) (Бучко \& Бучко, 2002), О. С. Вербовецька (Тернопільщина) (Вербовецька, 2011), Р. І. Осташ (Івано-Франківщина) (Осташ, 2000, 2001), П. П. Чучка (Закарпаття) (Чучка, 2008). Неофіційні спадкові іменування Західного Полісся вивчали Г. Л. Аркушин (Аркушин, 2009), Н. М. Шульська (Шульська, 2010). Сімейно-родові іменування півдня Волинської області початку XX ст. не були предметом наукового вивчення.

Сімейно-родові спадкові іменування залишаються активним типом іменувань у сучасному сільському антропоніміконі Волині, частина таких назв дуже давня, їхню мотивацію та першоносія визначити здебільшого 
неможливо, хоча така інформація дозволила 6 проаналізувати питання давності цих назв. Особливу цінність становлять сімейно-родові іменування, давні за походженням, адже в їхніх основах збережені давні варіанти імен та прізвиська.

Об'єкт нашого дослідження - сімейно-родові іменування початку XX ст. в антропоніміконі Волині (на матеріалі антропонімії сіл Антонівка та Борисковичі). Предмет дослідження - мотивація та семантика основ відіменних та відпрізвищевих сімейно-родових іменувань. Матеріалом для дослідження слугували сімейно-родові іменування, які активно функціонували в середині XX ст. та збережені в сучасному антропоніміконі, але поступово зазнають занепаду, замінюючись новими сімейно-родовими іменуваннями.

Сімейно-родові іменування, збережені з початку та середини XX ст., ідентифікують численних представників одного роду, засвідчують у своїх основах особову назву предка, спільного для чотирьох-п'яти поколінь. Мотивація та походження основ таких іменувань зазвичай втрачені та незрозумілі для носіїв цих назв. На відміну від власне прізвиськ, якими називають поза очі, сімейно-родові іменування не образливі для носіїв, а виконують вирізняльну функцію. Наявність таких іменувань була актуальною для сільського антропонімікону, якому до середини XX ст. був притаманний обмежений репертуар імен, а також усталений та повторюваний для різних родин перелік прізвищ.

Серед сімейно-родових іменувань початку XX ст., засвідчених в селах Антонівка та Борисковичі Горохівського району Волинської області, переважають іменування, похідні від чоловічого особового імені:

Ахтамо́нові $<$ Ахтамо́н < Автоном (Бор.),

Валєнтові (Валєнти́) < Валєнтий < Валентин (пор. засвідчений у селі мікротопонім Свєнтий Валєнтий) (Бор.),

Вїцкові (Віцики) < Ві́ико < Вікентій (Бор.),

Вла́дикові < Вла́дик < Володимир (Бор.),

Вло́дьові < Вло́дво < Володимир (Бор.),

Гарти́мові < Гарти́м < Артем (Бор.),

Гарие́нтові (Гариенти́) < Гарие́нтий < Арсентій (Бор.),

Ги́вові < Ги́ва < Іов (Бор.),

Гоно́фрові < Гоно́фрий < Онуфрій (Бор.),

Дьо́дикові < Дьо́дик < Володимир (Бор.), 
Ївану́ньові (Ївануні) < Ївану́нь > Іван (Бор.),

Їва́нькові (Їваньки́) < Їва́нько > Іван (Бор.),

Їва́сикові < Їва́сик < Іван (Бор.),

Їро́нові (Їрони́) < Їро́н < Ієронім (Бор.),

Їськові (Їськи́) < Їсько < Йосип (Бор.),

Каїта́нові < Каєтан (польськ. Kajetan; див. Mytnik, 2010) (Бор.),

Касійо́нові < Касійо́н < Касьян (Бор.),

Ліка́нові < Ліка́н < Никандр (Бор.),

Лєвонові < Лєвон < Леонтій (Бор.),

Люнекові < Люнек < Леонід (Бор.),

Ма́ркові < Марко (Бор.),

Максими́ < Максим (Ант.),

Митрофа́нові < Митрофан (Бор.),

Михто́нові < Михто́н < Мебодій (Бор.),

Мілійо́нові < Мілійо́н < Омелян (Бор.),

Мільо́нові < Мільо́н < Омелян (Ант.),

Панько́ві < Панько́ < Пантелеймон (Бор.),

Си́дорові < Сидор (Ант.),

Тіхо́нові < Тихон (Бор.),

Те́миьвові < Те́ми,ьо < Тимобій (Бор.),

То́мкові < То́мко < Хома (Бор.),

Федо́нові < Федо́н < Феодосій (Бор.),

Юркові

Яшкові < Яшко < Яків (Бор.).

Одне з давніх сімейно-родових іменувань, яке активно функціонувало на початку та в середині XX ст. і відоме в сучасному антропоніміконі села Борисковичі - колективний антропонім Ві́икові, який обєєнує за походженням родини Баб'юків, Лагановських, Лащуків, Михальчуків, Міндюків, Щерблюків, Якубчуків та ін. На початку ХХ ст. до цієї родини належали три брати: Прокіп (1871 р. н.), Пилип (1866 р. н.), Максим (1881 р. н.) Стаховичі Лагановські (див. Ведомость 1929), яких уже називали антропонімом Вíusкові. Оскільки в Пилипа було 7 дітей, а в Прокопа та Максима - по 4 дітей, народжених у період із 1900 до 1927 року, то родина Віцкових до кінця XX - початку XXI ст. значно розгалузилася. 
Відомості про Прокопа, Пилипа та Максима Лагановських не можуть прояснити часу виникнення антропоніма Bíusкві, який, очевидно, мотивований варіантом імені Віน,ко, розмовною формою імені Вікентій. Метрична книга Троїцького храму села Борисковичі 1866 року містить запис про народження Филипа Стахіева Лагановского з інформацією про батьків: Стахій Вікентіевъ Лагановскій та дружина Анастасия Яковлева (МК Борисковичі 1866). Очевидно, що існував Вікентій Лагановський, дід по батькові названих вище братів, ім'я якого стало основою для сімейно-родового іменування Ві́ц,кові.

У книзі шлюбів 1860 року знаходимо запис про шлюб двадцятирічного Стахія Вікентіева Лагановского з двадцятирічною Анастасией Яковлевой Цисаревой. У цій же книзі є запис про свідка одного зі шлюбів Вікентія Матфеева Лагановского (КБО Борисковичі 1860). Книга записів про народження, шлюби і поховання Горохівського костелу 1800-1817 рр. містить польськомовний запис про народження Вікентія Матвійовича Лагановського, датований 1809 роком (KMU Горохів 1800-1817). Спираючись на архівні матеріали, можна стверджувати, що колективний антропонім Вї́кові виник у 1850-1860 pp. для позначення насамперед дітей Вікентія Матвійовича Лагановського, що уможливило збереження цього іменування та його перехід до наступних поколінь. Отже, сімейно-родові іменування в окремих випадках можуть проіснувати в сільському антропоніміконі понад 100-150 років.

Ще одне цікаве та давнє сімейно-родове іменування - антропонім Самсо́новi, який досі активно функціонує в антропоніміконі села Борисковичі, охоплюючи родини Гасів, Павліків, Лащуків та ін. Для аналізу походження цього антропоніма достатньо інформації респондентів, за якою Самсо́новими називали братів Івана (1861 року народження), Спиридона (1879 року народження) та Тимофія (рік народження невідомий) Самсоновичів Павліків (роки народження подаємо за сповідною книгою Іовського храму села Борисковичі 1929 року - Ведомость 1929). Окрім інформації респондентів залучаємо матеріали сповідної книги 1929 року (Ведомость 1929), де згадано Івана та Спиридона Самсоновичів Павліків, а також вміщено списки їхніх сімей (Тимофій Павлік на той час, за інформацією респондентів, мешкав у сусідньому селі Брани). Оскільки Самсо́новими називали синів Самсона Павліка та їхніх нащадків, то припускаємо, що це сімейно-родове іменування виникло в 1890-х роках.

В антропоніміконі досліджуваних сіл наявний ряд сімейно-родових іменувань, похідних від андронімів, іменувань жінки за іменем чоловіка: 
Карпи́шині < Kарпи́ха < Kарпо (Бор.),

Ко́стишинi < Ко́стиха < Кость < Костянтин (Бор.),

Гандру́щишині < Гандру́щиха < Гандру́шко < Андрій (Ант.),

Макари́шки < Макари́ха < Макар (Ант.),

Степани́шині < Степани́ха < Степан (Ант.),

Яийнишині < Яийниха < Яиъь < Яків (Бор.).

Жіночими іменами мотивовані сімейно-родові іменування:

Галі́нині < Галина (Бор.),

Ганютині $<$ Ганюта < Ганна (Бор.),

Га́nчині < Га́nка < Агаббія (Бор.),

До́мчині < До́мка < Домникія (Бор.),

$€ в к u ́<\epsilon в к а<€ в а$ (Ант.),

Зо́ньчині < Зо́нька < Софія (Бор.),

Зо́сіні < Зо́ська < Собія (Бор.),

Їбро́нині < Їфро́на < Єळросинія (Бор.),

Ліке́рчині < Ликера (Бор.),

Льо́діні < Льо́дя < Людмила (Бор.),

Пала́жчині < Пала́жка < Пелагія (Бор.),

Пара́ніні < Пара́нька < Параскева (Бор.),

Сіво́нчині < Сіво́нка < Соломія (Ант., Бор.),

Сте́пчині < Сте́nка < Степанида (Бор.),

Та́циині < Та́цька < Тетяна (Бор.),

Юльчині < Юлька < Юлія (Бор.),

Яри́нчині < Ярина < Ірина (Бор.).

Вагому частину сімейно-родових іменувань охоплюють антропоніми, похідні від прізвища першоносія. Сучасне іменування Заби́ткові респонденти кваліфікують як похідне від прізвиська Заби́тко, яке начебто виникло через те, що першоносій випадково вбив сина вилами. Проте книга шлюбів села Борисковичі 1900 року містить інформацію про шлюб Івана Климовича Філата та Любові Василівни Забитко (КБО Борисковичі 1900), а сповідна книга 1929 року містить інформацію про 15 людей із прізвищем Забитко (три родини) (Ведомость 1929). Зрозуміло, що давність антропоніма Заби́тко та відповідного сімейно-родового іменування значно більша, оскільки він функціонував як індивідуальне прізвисько, 
що стало прізвищем, тоді ж виникло й неофіційне сімейно-родове іменування Заби́тковi, яке збереглось навіть після занепаду юридично закріпленого варіанта та існує вже близько 100 років.

Подібна ситуація склалася із сімейно-родовим іменуванням Якубе́йцеві (Якубейці́), яке містить в основі ім’я Якуб, i, на перший погляд, виникло безпосередньо від імені предка, проте навіть поверхневий аналіз давніх метричних записів, книг шлюбів села Борисковичі спростовує цю гіпотезу, оскільки одним із найбільш поширених у цьому населеному пункті було прізвище Якубейко, представлене десятками записів про народження та шлюби впродовж усього XIX ст. як у православних, так і в католицьких церковних документах. У книгах шлюбів 1896-1900 рр. та в сповідній книзі села Борисковичі 1929 року це прізвище відсутнє. Отже, спочатку виник варіант імені, який пізніше став функціонувати як прізвисько або сімейно-родове іменування, що згодом закріпилося як прізвище і після занепаду прізвища збереглося в формі сімейно-родового іменування Якубе́йцеві.

Значна частина сімейно-родових іменувань мотивовані прізвищем першоносія:

Бляхарі< Бляхар (Ант.),

Бо́ндарові (Бондарі́) < Бондар (Бор.),

Ге́ливі < Гель (Бор.),

Гриби́ < Гриб (Бор.),

Ле́бидьові < Лебідь (Бор.),

Ліминнові < Ліщина (Бор.),

Мо́йкові < Мойко (Бор.),

Нетреби́ < Нетреба (Ант.),

Пали́кові < Палига (Бор.),

Пушкаре́нкові < Пушкаренко (Бор.),

Ру́съовi < Русь (Бор.),

Сені < Сень (Ант.),

Середо́вi < Середа (Бор.),

Фі́латові (Філа́mu) < Фі́лат (Бор.),

Ціссарові < Цісар (Бор.),

Чижі < Чиж (Ант.),

Чорноклиммові < Чорноклим (Бор.),

Шимчуко́ві < Шимчук (Бор.). 
До середини - другої половини XX ст. в селі Борисковичі був відомий сталий вислів: То Го́пичка, то По́пччка, то Пу́ндичка, то Пу́ришка, Як не Го́пичка, то По́пччка, як не Пу́ндичка, то Пу́ришка, який відображав невелику різноманітність прізвиськ у селі (вислів записано від Лісової Лідії Іванівни, 1934 р. н.). Спадковий антропонім По́nикові зберігся в селі досі, По́nичка представниця родини, яку називали неофіційним колективним антропонімом По́nикові (Попики́). Неофіційний антропонім Пу́ндичка виник від прізвища Пундик, яке було поширеним у селі Борисковичі та сусідніх селах Довгів і Цегів протягом усього XIX ст., існує в сучасному антропоніміконі села Борисковичі. Антропоніми Го́пичка та Пи́ришка респондентці були невідомі. Метрична книга села Борисковичі 1849 року містить запис про народження дитини з прізвищем Пуръ (МК Борисковичі 1849), а книга шлюбів 1880 року містить запис про шлюб Петра Петровича Пури (Н. в. - Пура) (КБО Борисковичі 1880). Отже, антропонім Пу́ришка виник від прізвища Пур, Пура, яке, очевидно, існувало в двох варіантах. Походження неофіційного антропоніма Го́nичка, засвідченого в наведеному вислові, потребує подальшого дослідження.

Отже, сімейно-родові іменування як особливий різновид прізвиськ зберігають надзвичайно цінну інформацію про варіанти імен та прізвища, давність яких часто сягає понад 100-200 років. Сімейно-родові іменування засвідчують особову назву першоносія (Ві́иякові, Самсо́нові) або містять вказівку на втрачене прізвище (очевидно, внаслідок змін прізвища після заміжжя), давність іменувань цього типу ще більша. Водночас сімейно-родові іменування - своєрідний ключ до інформації про походження родини, належність до певного роду, цінний матеріал для вивчення родоводу, краєзнавчих досліджень. Наявність давніх сімейно-родових іменувань збагачує антропонімну систему конкретного населеного пункту, сімейно-родові іменування виступають специфічним та невід’ємним елементом сільського антропонімікону.

Джерела дослідження

Ведомость 1929 - Ведомость за 1929 годъ обретающимся при Іовской церкви села Борисковичъ въ приходе нижеявленныхъ чиновъ людямъ, со изъявлениемъ противъ коегождо имени о бытии ихъ въ Святую Четиредесятницу у Исповеди и Святыхъ Тайн Причастия.

КБО Борисковичі 1860 - Книга брачныхъ обысковъ за 1860 г. Троицкая церковь села Борисковичи Владимир-Волынскаго уезда (Державний архів Волинської області, далі - ДАВО). 
КБО Борисковичі 1880 - Книга брачныхъ обысковъ за 1880 г. Троицкая церковь села Борисковичи Владимир-Волынскаго уезда (ДАВО).

КБО Борисковичі 1900 - Книга брачныхъ обысковъ за 1892-1902 гг. Троицкая церковь села Борисковичи Владимир-Волынскаго уезда (ДАВО).

КИ Борисковичі 1852 - Книга исповедания прихожанъ Свято-Троицкой церкви села Борисковичи за 1852 годъ (ДАВО).

МК Борисковичі 1849 - Метрическая книга записи о рождении за 1849 г. Троицкая церковь села Борисковичи Владимир-Волынскаго уезда (ДАВО).

МК Борисковичі 1866 - Метрическая книга записи о рождении за 1866 г. Троицкая церковь села Борисковичи Владимир-Волынскаго уезда (ДАВО).

KMU Горохів 1800-1817 - Księga metrykalna urodzeń, ślubów, zgonów, par. Horochów, dek. Włodzimierz Wołyński. 1800-1817 (ДАВО).

\section{Бібліографія}

Beneš, J. (1962). O českých přijmeních. Nakl. Československé Akad. Věd.

Biolik, M. (1983). Przezwiska i przydomki ludności wiejskiej (na przykładzie wsi Andrzejki w województwie łomżyńskim). Onomastica, 28, 165-179.

Blanar, V. (1998). Klasifikácia priezvisk. In П. Чучка (Ed.), Слов’янська ономастика (pp. 221-226). ТОВ “Папірус".

Cieślikowa, A. (1998). Przezwiska. In E. Rzetelska-Feleszko (Ed.), Polskie nazwy własne: Encyklopedia (pp. 119-134). Instytut Języka Polskiego Polskiej Akademii Nauk.

Kazík, M. (2016). Živé osobné mená a pomenovacie modely v triede slobodných osôb v Papradi. Acta Onomastica, 58, 58-71.

Lindert, B. (1966). Przyrostki używane w funkcji patronimicznej na terenie woj. lubelskiego. Język Polski, 1966(4-5), 284-292.

Mytnik, I. (2010). Antroponimia Wołynia w XVI-XVIII wieku. Uniwersytet Warszawski.

Sajewicz, M. (1999). Przezwiska mieszkańców kilku wsi z białorusko-ukraińskiego pogranicza językowego na Białostocczyźnie. In S. Warchoł (Ed.), Przezwiska i przydomki w językach słowiańskich (pp.69-70). Wydawnictwo Uniwersytetu Marii Curie-Skłodowskiej.

Sychta, B. (1956). Przezwiska Kaszubów. Język Polski, 36(2), 97-108.

Tomczak, L. (1999). Antroponimy nieoficjalne mieszkańców Sutkowa. In S. Warchoł (Ed.), Przezwiska i przydomki w językach słowiańskich (pp. 203-215). Wydawnictwo Uniwersytetu Marii Curie-Skłodowskiej.

Аркушин, Г. (2009). Словник прізвиськ північно-західної України: У 3-х т. РВВ “Вежа" Волин. нац. ун-ту ім. Лесі Українки.

Бірыла, М. (1966). Беларуская антрапанімія: Уласныя імёны, імёны-мянушкі, імёны па бацьку, прозвішчы. Навука і тэхніка. 
Бучко, Г., \& Бучко, Д. (2002). Народно-побутова антропонімія Бойківщини. In I. Желєзняк (Ed.), Linguistica slavica (pp. 3-14). Кий.

Вербовецька, О. (2011). Сімейно-родові іменування, мотивовані особовими іменами (на матеріалі антропонімії Тернопільщини). Вісник Прикарпатського національного університету імені Василя Стефаника: Філологія, 29-31, 303-307.

Осташ, Р. (2000). Із життя сучасних українських прізвищ: 1. In I. Желєзняк (Ed.), Українська пропріальна лексика (рр. 115-121). Кий.

Осташ, Р. (2001). Із життя сучасних українських прізвищ: 2. In Д. Бучко (Ed.), Українське і слов'янське мовознавство (pp. 408-412). Вид-во Олександри Гаркуші.

Пахомова, С. (2012). Еволюиія антропонімних формул у слов'янських мовах. Вид-во Олександри Гаркуші.

Чучка, П. (2008). Антропонімія Закарпаття. ТОВ “Папірус".

Шульська, Н. (2010). Сімейно-родова антропонімія Західного Полісся. Украӥнська мова, 2010(2), 50-59.

\section{Bibliography (Transliteration)}

Arkushyn, H. (2009). Slovnyk prizvys'k pivnichno-zakhidnoï Ukraïny: U 3-kh t. RVV "Vezha” Volyn. nats. un-tu im. Lesi Ukraïnky.

Beneš, J. (1962). O českých přijmeních. Nakl. Československé Akad. Věd.

Biolik, M. (1983). Przezwiska i przydomki ludności wiejskiej (na przykładzie wsi Andrzejki w województwie łomżyńskim). Onomastica, 28, 165-179.

Biryla, M. (1966). Belaruskaia antrapanimiia: Ulasnyia imiony, imiony-mianushki, imiony pa bats'ku, prozvishchy. Navuka i tèkhnika.

Blanar, V. (1998). Klasifikácia priezvisk. In P. Chuchka (Ed.), Slov'ians'ka onomastyka (pp. 221-226). TOV "Papirus".

Buchko, H., \& Buchko, D. (2002). Narodno-pobutova antroponimiia Boŭkivshchyny. In I. ZHeliezniak (Ed.), Linguistica slavica (pp. 3-14). Ky̆̌.

Chuchka, P. (2008). Antroponimiia Zakarpattia. TOV "Papirus".

Cieślikowa, A. (1998). Przezwiska. In E. Rzetelska-Feleszko (Ed.), Polskie nazwy własne: Encyklopedia (pp. 119-134). Instytut Języka Polskiego Polskiej Akademii Nauk.

Kazík, M. (2016). Živé osobné mená a pomenovacie modely v triede slobodných osôb v Papradi. Acta Onomastica, 58, 58-71.

Lindert, B. (1966). Przyrostki używane w funkcji patronimicznej na terenie woj. lubelskiego. Język Polski, 1966(4-5), 284-292.

Mytnik, I. (2010). Antroponimia Wołynia w XVI-XVIII wieku. Uniwersytet Warszawski.

Ostash, R. (2000). Iz zhyttia suchasnykh ukraïns'kykh prizvyshch: 1. In I. ZHeliezniak (Ed.), Ukraïns'ka proprial'na leksyka (pp. 115-121). Kyı̆. 
Ostash, R. (2001). Iz zhyttia suchasnykh ukraïns'kykh prizvyshch: 2. In D. Buchko (Ed.), Ukraïns'ke i slov'ians'ke movoznavstvo (pp. 408-412). Vyd-vo Oleksandry Harkushi.

Pakhomova, S. (2012). Evoliutsiia antroponimnykh formul u slov'ians'kykh movakh. Vyd-vo Oleksandry Harkushi.

Sajewicz, M. (1999). Przezwiska mieszkańców kilku wsi z białorusko-ukraińskiego pogranicza językowego na Białostocczyźnie. In S. Warchoł (Ed.), Przezwiska i przydomki w językach słowiańskich (pp. 69-70). Wydawnictwo Uniwersytetu Marii Curie-Skłodowskiej.

Shul's'ka, N. (2010). Simeĭno-rodova antroponimiia Zakhidnoho Polissia. Ukraïns'ka mova, 2010(2), 50-59.

Sychta, B. (1956). Przezwiska Kaszubów. Język Polski, 36(2), 97-108.

Tomczak, L. (1999). Antroponimy nieoficjalne mieszkańców Sutkowa. In S. Warchoł (Ed.), Przezwiska i przydomki w językach słowiańskich (pp. 203-215). Wydawnictwo Uniwersytetu Marii Curie-Skłodowskiej.

Verbovets'ka, O. (2011). Simerno-rodovi imenuvannia, motyvovani osobovymy imenamy (na materiali antroponimiï Ternopil'shchyny). Visnyk Prykarpats'koho natsional'noho universytetu imeni Vasylia Stefanyka: Filolohiia, 29-31, 303-307.

\section{Family Names Derived from Given Names and Surnames: A Study of Selected Anthroponyms in the Villages of Antonivka and Boryskovychi in the Early to Mid-Twentieth Century}

\section{Summary}

This article analyses the origins of family names and the duration of their functioning in rural anthroponymics on the basis of the anthroponymy of the south of the Volyn region in the early to mid-twentieth century. The study examines the semantic and word-formation structure of anthroponyms in the area, identifies lexico-semantic groups represented in the roots of family names, and considers different structural variants of the given names and surnames from which family names were derived, including their productivity and the most frequent cases. The semantics of roots and the word-formation structure of family names in the south of the Volyn region reflect general tendencies of the Ukrainian anthroponymic system and tendencies of the regional anthroponomy, which stem 
from dialectal features, influences of other languages, and historical and cultural peculiarities of the region.

\title{
Nazwy rodowe pochodzące od imion i nazwisk pierwszych użytkowników (na podstawie wybranych antroponimów wsi Antonówka i Boryskowicze z początku i połowy $\mathrm{XX}$ wieku)
}

\author{
Streszczenie
}

W artykule przeanalizowano problem pochodzenia nazw rodowych oraz czasu ich funkcjonowania w antroponimikonie wiejskim (na podstawie antroponimów na południu obwodu wołyńskiego z początku i połowy XX wieku). Autorka analizuje strukturę semantyczną i słowotwórczą antroponimów w tym regionie, przedstawia grupy leksykalno-semantyczne reprezentowane w podstawach nazw rodowych, omawia różne pod względem strukturalnym warianty imion i nazwisk motywujące nazwy rodowe. W artykule określono produktywność imion motywujących nazwy rodowe i zidentyfikowano najbardziej aktywne imiona. Semantyka podstaw i struktura słowotwórcza nazw rodowych z południa obwodu wołyńskiego odzwierciedlają ogólne tendencje ukraińskiego systemu antroponimicznego, a także cechy regionalne antroponimii wynikające z właściwości gwarowych, wpływów innych języków oraz cech historycznych, kulturowych i obyczajowych regionu.

Keywords: family nomination; anthroponym; given name; appellative; word-formation group

Słowa kluczowe: nazwa rodowa; antroponim; imię; apelatyw; grupa słowotwórcza

Larysa Sadova, Lesya Ukrainka Volyn National University, Lutsk, Ukraine

Correspondence: lisova88@ukr.net

The preparation of this article was self-financed by the author.

Competing interests: The author has declared that she has no competing interests. 